\title{
BALANCED OR UNBALANCED DEVELOPMENT? AN EVALUATION APPROACH TO TOURISM DEVELOPMENT IN SOUTH TRANSDANUBIA, HUNGARY
}

\author{
JÁNOS CSAPÓ* \\ University of Pécs, Faculty of Business and Economics, Institute of Marketing and Tourism, Hungary \\ * Corresponding author: csapo.janos@ktk.pte.hu
}

\begin{abstract}
Investigating the effectiveness of regional tourism support is always relevant in tourism research, especially in the European Union. However, in recent decades researchers and regional development actors concentrated predominantly on concrete financial-economic aspects based on the monitoring systems of the European integration. Based on this circumstance, the principal objective of this article is to offer various aspects on the research of the effectiveness of tourism subsidies, employing a spatial-geographical perspective. The article aims to determine whether there is a correlation between the presence of tourism attractions, existing tourism demand, and the regional allocation of the awarded subsidies. An elaborate evaluation approach was applied in a NUTS 2 region of Hungary, South Transdanubia. However, the method can be used in different regional levels as well since it is based on settlement-level data. Another claim of the article is that the demonstrated monitoring aspects can further contribute to a more effective regional policy approach concerning the evaluation of tourism developments.
\end{abstract}

Keywords: tourism development, tourism support, correlation, South Transdanubia, regional development, evaluation method

Received 16 December 2016; Accepted 26 September 2017; Published online 10 October 2017

\section{Introduction}

From the second half of the 20th century, it became evident that one of the engines of world economy and a remarkable development force is tourism (Lew et al. 2008; Meyer 2011; Sánchez-Rivero, Cárdenas-García 2014). Since tourism is made up of processes of a timely and spatial nature, it contributes to the formation of a system of sending and host regions, displaying the unique social-economic and environmental characteristics of the localities (Sharpley 2015; Aubert et al. 2015). It is crucial to stress that the regional connections of tourism and the presence of locality are essential since the majority of tourism attractions are based on the attractions of the region, landscape, or local culture. If this area is coupled with an adequate tourism supply, tourism begins to form spatial processes, since it affects settlement structure, employment, spatial relations or the environment, lifestyle and quality of life (Lew et al. 2008; Hall 2012). Thus, regional analyses employing different perspectives should focus more on the processes of tourism since this branch will influence increasing spaces in the world economy (Cole 2007; Jopp et al. 2010; Viken, Granas 2014). Today, the tourism world market creates a coherent and interdependent system wherein both supply and demand go through significant changes in time and space in terms of quantitative and qualitative aspects and components (Conrady, Buck 2010; Dwyer, Kim 2010; Theobald 2011; von Bergner, Lohmann 2014).
The present study intends to demonstrate a comparative regional (settlement-level) and spatial analysis of the spatial distribution of tourism attractions and products, apparent and statistically detected demand, tourism support and the general development level of settlements. The central question of this survey is whether the correlation between the determined attraction survey, the tourism supply and demand and the regional allocation of tourism support sources is interrelated, or whether we can find anomalies and inappropriate practice in the tourism development processes. Furthermore, the paper discusses the correlation between the general development level of a settlement and of its tourism. All these aspects are investigated in a case study in a NUTS 2 region of Hungary, South Transdanubia.

According to the author's hypothesis, several kinds and levels of correlation will be determined during the investigations. First, it is investigated whether we can find any attractions at a specific location. Second, we need to determine if there is an adequate volume of tourism infrastructure. Third, we investigate if there is any tourism demand detected at the settlement. Correlation may also be demonstrated in most cases between the development level of the settlements and their tourism potentials. This aspect of the research focuses on any correlation between the general development level of a settlement (developed and determined by the Central Statistical Office of Hungary) and the quality and quantity of tourism. A further viewpoint of this research is the examination 
of whether the regional allocation of tourism subsidies has been expended on the most adequate locations where regional development and tourism planning would objectively allocate them. Summing up, the subject matter of this paper is the survey of the settlement level relations among the supply and demand of tourism and the spatial-economic differences.

\section{Literature review}

Evaluating the spatial dynamics of tourism is a reasonably well focused direction of tourism research (Hall 2008, 2012; Connell 2009; Yaoqing 2011). The different approaches of these investigations on destination planning, economic and social impacts became fundamental for modern tourism research and for the creation of regional tourism policies both in general (Butler 1980; Font, Ahjem 1999) and as regards regional perspectives (Terluin 2003; Archer, Fletcher 1996).

We basically know those models that evaluate certain factors and impacts of tourism, such as those developed by Williams and Cartee (1991), Crompton and Shuster (2001), Crompton (2006) and Dwyer et al. (2004), which are concerned with the economic impacts of tourism or the economic evaluation and measurement possibilities of these impacts. Hall and Boyd (2005) evaluated the relationship between peripheries and tourism, but few researchers tried to analyse the factors spatially and the impacts of spatial dynamics of tourism. For example, Imran and Bhat (2013) published their findings on determining tourism potential in creating a destination based on balanced tourism development from a regional perspective (Kashmir Valley). A valuable contribution was carried out by the ESPON Monitoring Committee (2006), whose research team published important findings on the spatially relevant aspects of tourism. Aubert et al. (2010) used complex geographical methods in order to determine the tourism destinations of a region. The spatial-geographical perspectives of Varjú et al. (2014) were emphasized when the authors introduced methods with landscape evaluation and target group preference weighting.

One of the closest studies to the present article was published by Deskins and Seevers (2011): the authors investigated whether state expenditures were effective in terms of tourism promotion and general economic growth. These investigations were carried out in U.S. states and focused on regression models to identify the effect of tourism support; however, they did not deal with geographical issues.

Another aspect of related research is the monitoring and evaluation approach to regional support of the European Union. A relatively great number of researchers dealt with creating a methodology in order to generally or comprehensively evaluate cohesion policy. BoschDomènech and Escribano (1998) expanded professional knowledge with an evaluation index of the regional allocation of public funds. Bachtler and Wren (2006) and Busillo et al (2010) published the results of much broader research, such as the evaluation opportunities of the EU's cohesion policy and measuring the impact of European regional policy on economic growth. RodríguezPose and Fratesi (2004), Becker et al. (2010) and Armstrong et al. (2012) also analysed regional aspects of the allocation of support and grant systems. Significant focus on investigating the tourism relations of EU funding was primarily carried out and proposed by the European Commission. The most relevant of these working papers is the ex post evaluation of Cohesion Policy programmes 2007-2013 (European Commission, 2014). In addition to such general and comprehensive studies, member states also regularly publish evaluation papers, usually after the completion of a particular planning period, but these approaches focus on economic aspects with no regard for complex spatial relations.

This paper extends these earlier works by applying spatial-geographical methods in the evaluation processes of the spatial dynamics of tourism in Hungary, South Transdanubia. As regards the expected outcomes and results, this work may assist a more effective decision-making process, at the same time reducing risks of the planning processes and provide a geographical approach for the monitoring indicators.

\section{Research methods}

The municipal-level regional investigation of the spatial distribution of tourism requires a complex methodology in analysing both tourism supply and tourism demand. In order to achieve this, the following methods were utilised:

A scientifically accurate, up-to-date tourism attraction survey and tourism product portfolio was carried out for the region. This first stage of the research was based on the Attraction Survey carried out by the Hungarian Tourism Ltd. in 1997. This survey covered all the settlements of Hungary, collecting data on three types of attractions: physical natural, cultural and special attractions. These were later evaluated on a uniform criteria scale, with values ranging from 1 to 9 for any attractions, in which 1 meant an attraction of local significance and 9 an attraction of international importance (Aubert et al. 2010).

The data of this attraction survey was updated and re-evaluated by the author during 2011-2013 where the settlements of the South Transdanubian NUTS II region were personally visited carrying out an updated attraction survey of 5,000 items (attractions) for the 656 settlements. In this process the methodology of the 1997 Attraction Survey and Aubert et al. (2010) was used (the evaluation method of the attractions from 1-9 is defined in detail in the Appendix). 
The attractions of the settlements were identified, collected, grouped, and rated by the determining tourism products. It should be highlighted that in this research the author used the aggregated result whether an attraction (with functioning attraction zone) or attractions can be found or not at the settlement. In this database only attractions were collected with at least 4 value points in the system of the 1997 Attraction Survey and Aubert et al. (2010): that is, those that can attract (statistically demonstrable) tourists, not only visitors (Appendix).

For the general spatial-statistical analysis the main indicators of tourism (statistically measurable data on commercial and private accommodations and guest flow) were provided by the official database of the Central Statistical Office (CSO) of Hungary. Also included in the survey were the spatial investigations of the financial supports received in favour of tourism from 2004-2013. Such data was received from the database of the Hungarian National Development Agency (2014). Finally, the complex settlement development index of the CSO of Hungary (HCSO, 2013) was also applied. This index was elaborated by the CSO, covering the complete range of social-economic indicators of Hungarian settlements. After the elaboration and weighting of the data, the settlements were classified in a 0-100 scale. For the survey the author listed the data relevant for the 656 settlements of South Transdanubia.
The results were obtained and map visualisations were carried out with GIS methods using ARC/GIS 9.2. ARC/ GIS Spatial Analyst. The numeric analysis was made by Microsoft Excel.

\section{Results and discussion}

\subsection{Municipal-level relations among tourism attractions, support sources, and spatial- economic differences}

When determining the presence of tourism generating attractions, altogether 207 settlements were categorised (with at least value number 4, see the Appendix), covering $31.55 \%$ of all the settlements in the region. Although the research also categorised the different tourism products and the absolute number of attractions, at this stage we only used information on whether or not tourism generating attraction or attractions were present at any settlement analysed.

After determining the spatial allocation of functioning tourism attractions, investigation of tourism demand indicators started. Based on the spatial presence of commercial and private accommodations in South Transdanubia, we can state that out of the 656 total settlements, 112 realised officially some level of accommodation turnover (Figure 1).

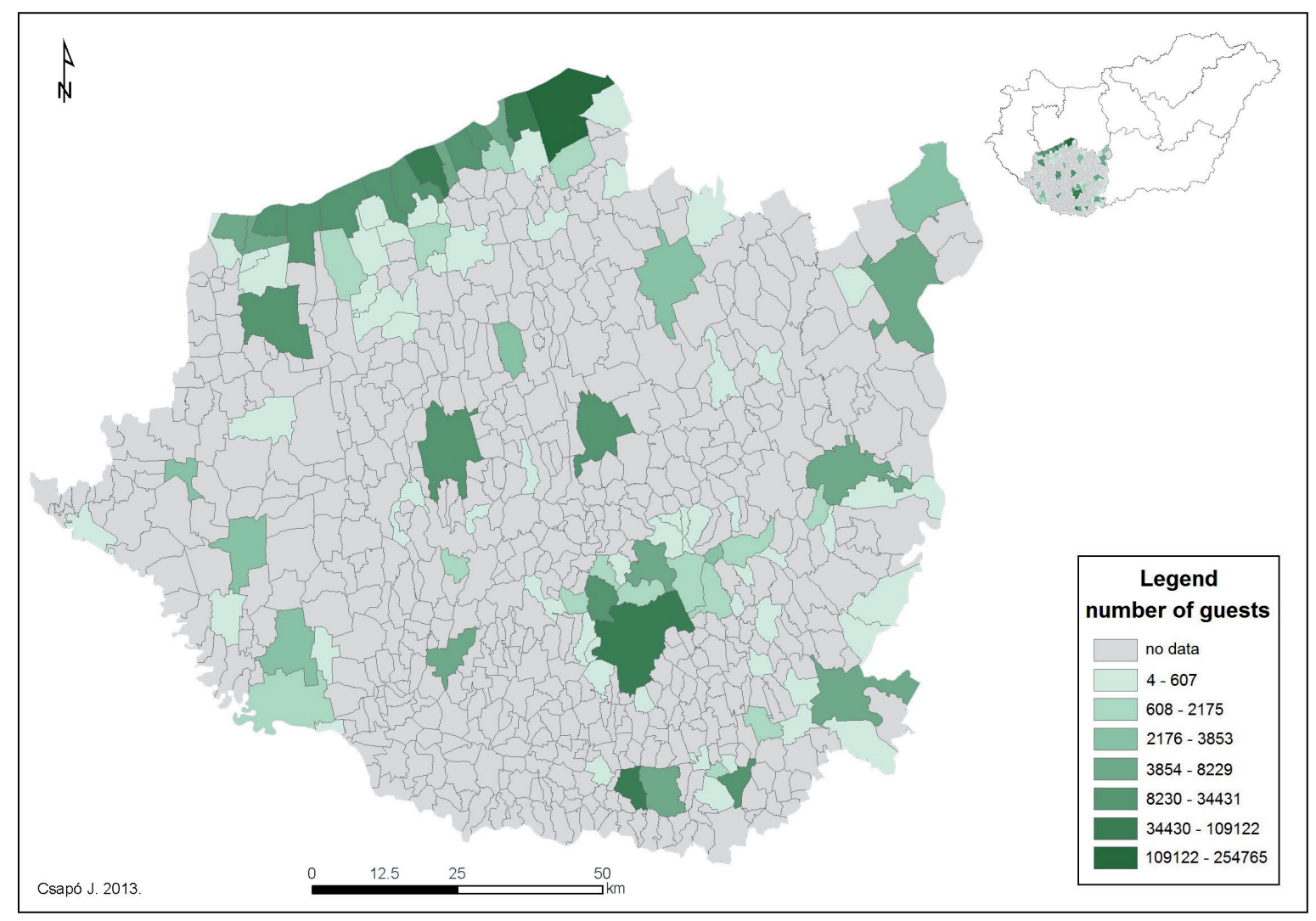

Fig. 1 The spatial distribution of all the turnover of commercial and private accommodations in South Transdanubia (2013). Source: Edited by the author, 2013. 


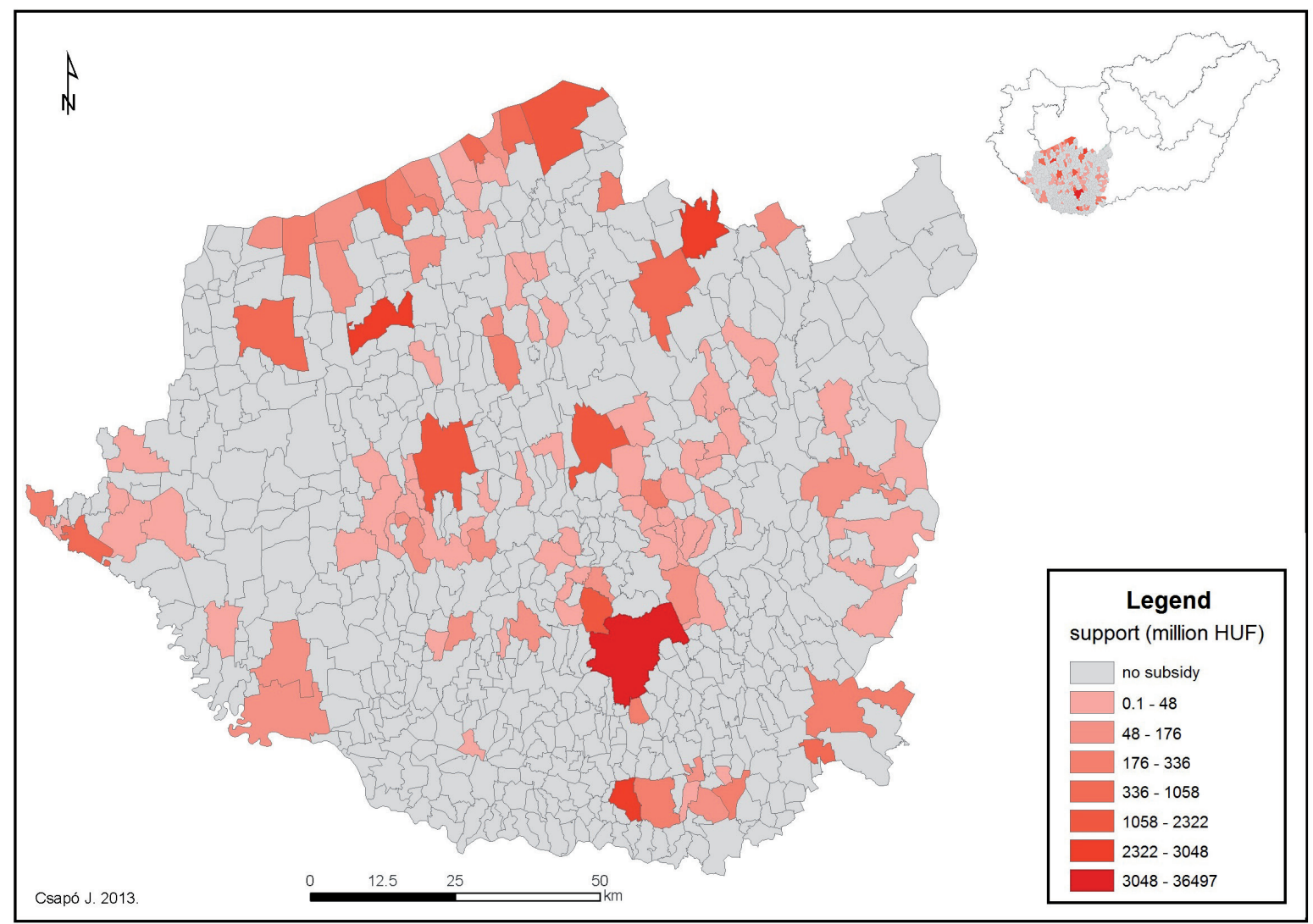

Fig. 2 The spatial allocation and quantity of tourism support sources in South Transdanubia. Source: Based on the database of the National Development Agency, 2013 edited by the author, 2013.

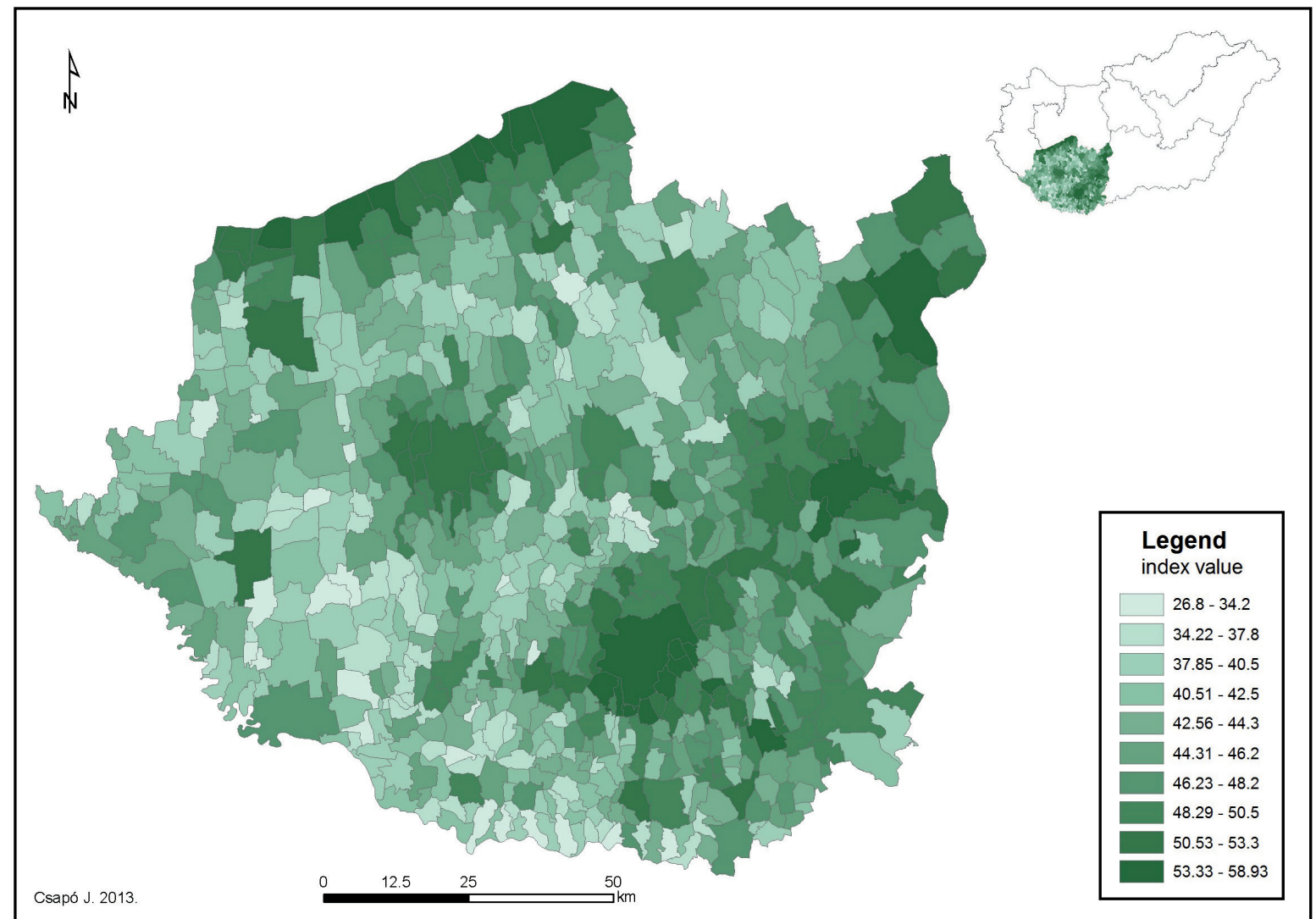

Fig. 3 The settlement development index of the CSO and its spatial distribution in South Transdanubia. Source: Based on CSO database, 2013 edited by the author, 2014. 


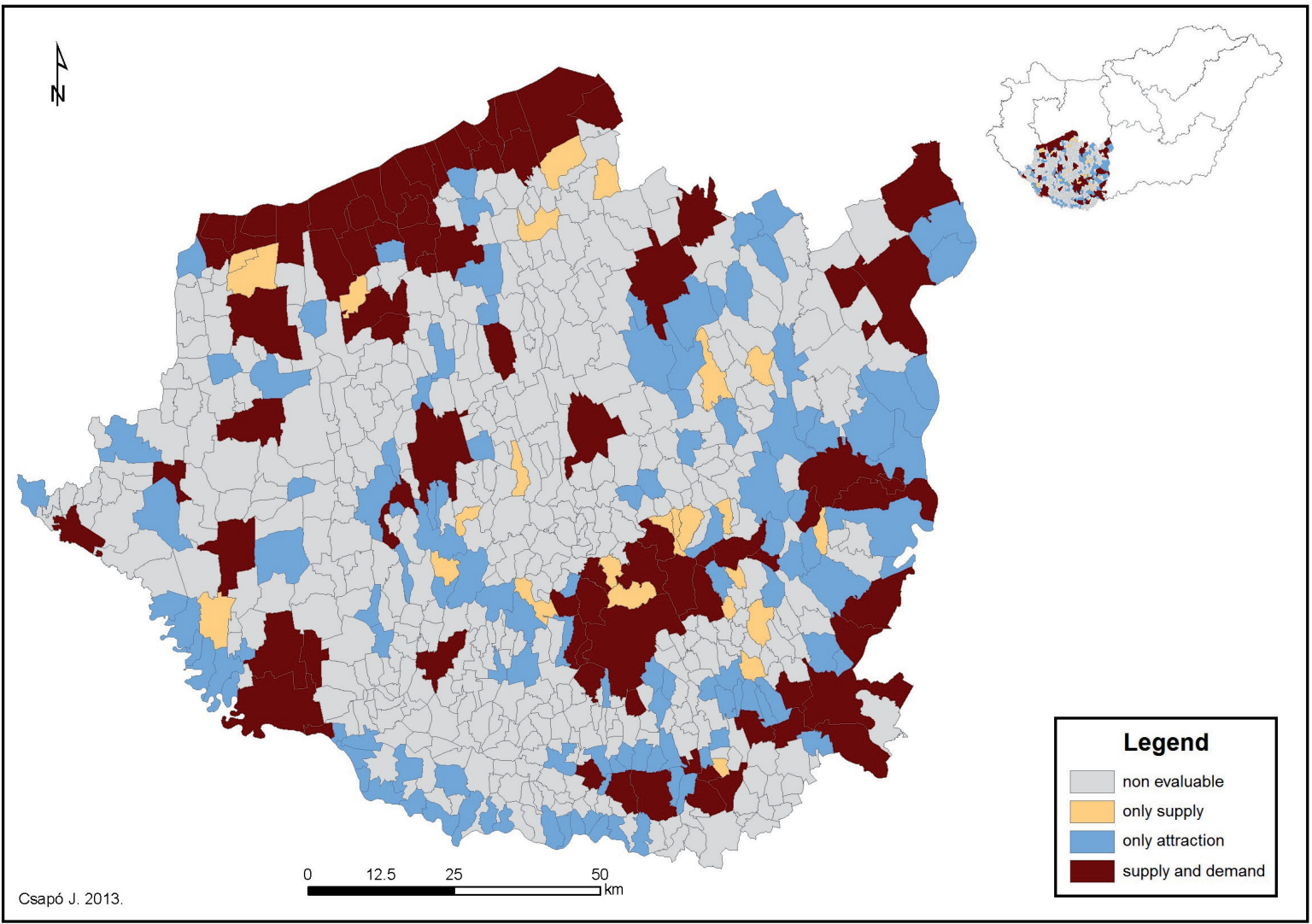

Fig. 4 The relationship between tourism attractions and the tourism demand (accommodations) in South Transdanubia. Source: Based on CSO database, 2013 edited by the author, 2013.

As the next step of the survey, the spatial allocation and the quantity of tourism support sources were identified. During the research, three EU planning periods were covered from 2004 (the joining of Hungary to the EU) to 2013 (end of the last EU planning period). The database was provided by the National Development Agency of Hungary (data downloaded in 2014). Out of these sources, all the projects directly connected to any form of tourism development were collected (accommodation development, tourism product development, tourism destination management development, cross-border programmes, infrastructure development, education programmes, fostering enterprises, and local product development) (Figure 2).

The last aspect of this part of the research was to spatially elaborate the settlement development index developed by the National Statistical Office of Hungary. As mentioned earlier this methodology is based on an evaluation and statistical weighting of complex social-economic aspects on a 0-100 scale. This research was carried out by the CSO in order to determine the preferential (underdeveloped) settlements - those micro regions where development sources should be allocated (105/2015. (IV. 23.) Governmental Regulation). In Figure 3 , the deviation of the index is illustrated between the maximum and minimum values of the South Transdanubian region (Figure 3).

\subsection{Comparative analyses after the elaboration of the collected databases}

As the first step of the qualitative comparative analysis, the relationship between the spatial appearance of tourism attractions and the presence of the guest flow of the accommodations was examined. Despite the fact that initially some anomalies were expected in the region in this respect (where, for instance, a highly appealing attraction is allocated in a settlement with no accommodation capacity), the quantity where there was no such coexistence was surprising.

Figure 4 (the settlements indicated in black) shows the coexistence of tourism accommodation demand and the attractions, so in this advantageous situation a certain demand is realised based on the existing tourism attractions.

Altogether, 226 such settlements were identified with some level or form of attraction and/or tourism demand comprising $34.45 \%$ of all the settlements of the region. A total of 81 of these settlements demonstrate both accommodation demand and tourism attraction, representing $35.68 \%$ of the 226 settlements. If we would like to evaluate the supply and demand relations of the region, this data proves to be disappointing; however, we understand that in numerous cases an attraction can be found in the vicinity of the settlement where there is only 


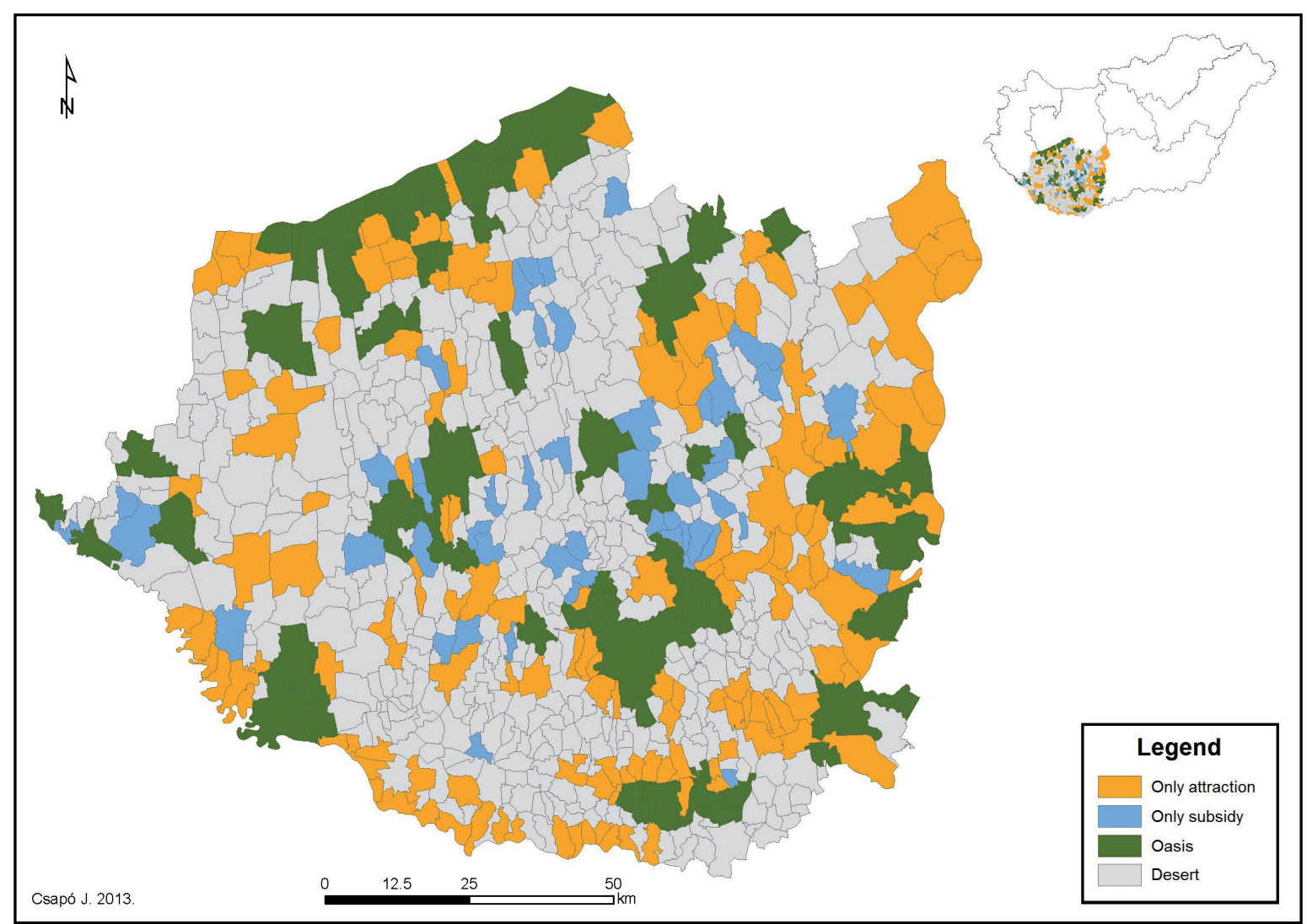

Fig. 5 The relationship between tourism attractions and tourism supports in South Transdanubia. Source: Based on National Development Agency database, 2013 edited by the author, 2013.

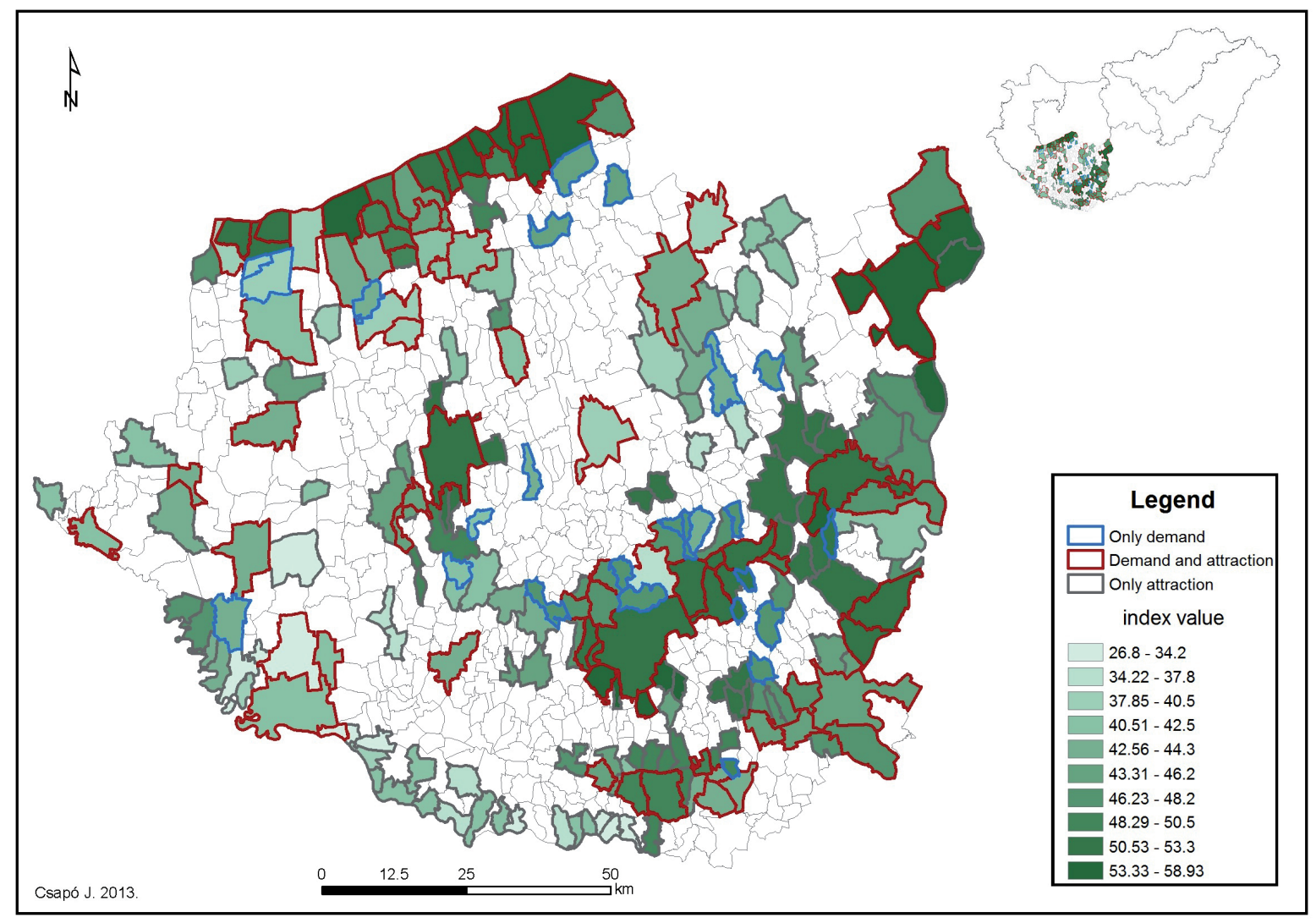

Fig. 6 The relationship between the CSO settlement development index and the presence of tourism (attraction, demand) in South Transdanubia.

Source: Based on HCSO database, 2013 edited by the author, 2013. 
accommodation, for instance. According to the survey, this figure grows only to $42-45 \%$, if we join these neighbouring settlements.

In this respect we have to state that entire regions lack tourism complexity (along the Drava and Danube rivers, internal parts of Tolna county, and the South of Somogy county). The number of settlements with only accommodation demand is 25 (or $11.06 \%$ of the 226 settlements), whereas the number of settlements with only tourism attractions is 120 (53.09\%). This data point clearly reflects that the presence of attractions of the region is inadequate to generate a certain kind of tourism demand (applying accommodations), which is also worrying, since only attractions that theoretically can generate functioning tourism flow were mentioned and used in this survey (above value point 4).

From this survey it seems that a complex and well-functioning tourism flow is realised only in settlements where both supply and generated demand are present, typically at waterside resorts (Lake Balaton), at health tourism centres (all the spas of the region), at cultural tourism, and at wine tourism centres. Only in the limited number of cases we can see active tourism generating supply and demand in the same settlement, especially in the case of hunting tourism.

The next phase of the research analysed the possible correspondence between the appearance of the tourism attractions and the spatial allocation of tourism support sources gained during the planning periods from 2004 to 2013. The basic question was whether it was evident that the registered tourism attraction(s) at a given settlement could generate functioning tourism flow where, besides the formation of demand, the need for tendering activity would appear as well, with tourism becoming a priority in the economic life of the settlement.

During the investigations it has been revealed that in the analysed region there are 405 settlements where there is neither tourism supply nor support. This group of settlements was entitled "desert" (Figure 5). Here one might expect that where there is no tourism attraction, one should detect no financial tourism support. However, further analysis highlighted numerous anomalies. For instance, there are 141 settlements where there is generated tourism supply from the point of view of attractions, but there is no detectable financial support. This would not be as worrying as the next result, according to which there are 49 settlements in South Transdanubia with (a certain amount of) financial support, but with no attractions whatsoever (Figure 5).

Of course, besides these raw numbers and figures, one should carry out an analysis with strong spatial-geographical perspective as well. Thus, the analysis involved the tourism structure of the neighbouring settlements (the presence of attractions, investments, and support), since the settlements are not necessarily allocated directly in the vicinity of a settlement with functioning tourism supply and demand. We also have to mention that investments belonging to this group primarily strengthened rural tourism, so they were only small/scale supports. Still, it is worth raising awareness of the fact that financial support was allocated for tourism development with no functioning tourism attraction in the locality.

The next group of settlements, called "oasis", was made up of 61 villages or towns where the tourism attractions and tourism supports were present as well (Figure 5). This group of settlements, the most viable in terms of tourism development and planning, where the presence of tourism provided adequate motivation for development activities, accounted for $9.3 \%$ of all the analysed settlements of the region.

It should be noted that in this research it was not the aim to find the exact reasons (political interest, corruption, or lack of professional knowledge) behind the outlined anomalies, since the author believes that it is extremely problematic to detect and prove objectively the mentioned presumptions.

The last segment of this research was a comparison of the spatial functioning of tourism and the settlement development level as determined by the CSO. Here the author was interested in whether the existing tourism activity of a settlement indicated automatically a more developed settlement level and whether a highly developed settlement possesses automatically a functioning and developed tourism as well.

For these investigations a map was created on the basis of the CSO database (Figure 6). On this map those settlements were indicated where there was tourism attraction and demand, only demand, or only tourism attractions. The figure clearly indicated that the settlements with tourism supply and demand did not necessarily belong to the most developed settlements. However, the majority of the most developed settlements possessed a real and functioning tourism. Nearly half of the settlements with tourism supply and demand at the same place belonged to the moderately or less developed group.

\section{Conclusions}

The most important aim of this research was to reveal possible anomalies of tourism development planning and practice from a geographical perspective in South Transdanubia, a Hungarian NUTS 2 region. The author believes that the presented research can provide useful results for such areas of interest as regional development and tourism, rural development and tourism and the spatial relations of the EU support sources. We received answers for the spatial relations concerning the presence or lack of tourism attractions, tourism supply, demand, spatial allocation of the EU financial sources and the development level of the region's settlements.

In the first phase of the research, an attraction survey was carried out in order to map the attraction structure and the spatial allocation of tourism supply. Results 
Tab. 1 Evaluation of Tourism Attractions by their Reach.

\begin{tabular}{|c|c|c|}
\hline $\begin{array}{l}\text { Attraction } \\
\text { value point }\end{array}$ & Attraction category, reach & Complementary terms \\
\hline 1 & $\begin{array}{l}\text { Local attraction 1: Can be developed to potential } \\
\text { attraction }\end{array}$ & $\begin{array}{l}\text { Local inhabitants know about the attraction and visit it, but without any } \\
\text { tourism flow. If a tourist arrives there - and obtains knowledge about it - } \\
\text { visits the place as a complementary program, but does not travel to the } \\
\text { settlement only because of that particular attraction. }\end{array}$ \\
\hline 2 & $\begin{array}{l}\text { Local attraction 2: With a reach and visit of a micro } \\
\text { region }\end{array}$ & $\begin{array}{l}\text { The neighbouring inhabitants are aware of it and show it to their guests. } \\
\text { It has a certain tourism flow as well but does not generate independent } \\
\text { demand. }\end{array}$ \\
\hline 3 & $\begin{array}{l}\text { Regional attraction 1: The majority of visitors come } \\
\text { from the given region; induces significant turnover }\end{array}$ & $\begin{array}{l}\text { It is a known, visited, and recognized attraction in the region, but is not } \\
\text { familiar outside the region; its external demand is negligible. }\end{array}$ \\
\hline 4 & $\begin{array}{l}\text { Regional attraction 2: The majority of the given } \\
\text { attraction's visitors arrive from the same region } \\
\text { but it also attracts visitors from settlements in the } \\
\text { neighbouring region (tourists from remote regions } \\
\text { or abroad are present but in small numbers) }\end{array}$ & $\begin{array}{l}\text { It is well known in its region, the population of the region consider it as part } \\
\text { of its image and visit it regularly. It is externally known as well outside the } \\
\text { regional boundaries and thus receives external visitors. }\end{array}$ \\
\hline 5 & $\begin{array}{l}\text { National attraction 1: The visitors of the attraction } \\
\text { come from the entire area of the country but } \\
\text { they only mean a special guest flow segment; } \\
\text { the attraction does not generate significant } \\
\text { international visits }\end{array}$ & $\begin{array}{l}\text { The attraction is completely accepted and accentuated in the region, } \\
\text { generating demand for one guest segment from the complete country } \\
\text { (e.g., a cross-country track) but does not motivate other segments. }\end{array}$ \\
\hline 6 & $\begin{array}{l}\text { National attraction } 2: \text { The visitors of the attraction } \\
\text { come from the entire country in every segment; } \\
\text { the attraction does not generate significant } \\
\text { international visits }\end{array}$ & $\begin{array}{l}\text { Generates visits in almost all visitor segments but is only known and } \\
\text { received by the domestic culture (linguistic, historical peculiarities) and has } \\
\text { no international attraction. }\end{array}$ \\
\hline 7 & $\begin{array}{l}\text { International attraction 1: A significant ratio } \\
\text { of visitors come from abroad but it is basically } \\
\text { attractive from one special segment (ratio of } \\
\text { domestic guests is lower) }\end{array}$ & $\begin{array}{l}\text { Its significant international guest flow has a special interest segment (e.g., } \\
\text { hunting tourism). }\end{array}$ \\
\hline 8 & $\begin{array}{l}\text { International attraction 2: A significant proportion } \\
\text { of visitors comes from abroad, representing a wide } \\
\text { range of segments (ratio of domestic guests is } \\
\text { lower) }\end{array}$ & $\begin{array}{l}\text { It attracts a significant international guest flow, mostly from neighbouring } \\
\text { countries and from traditional sending countries. Its demand is massive } \\
\text { but does not generate new markets in its present state, although it has } \\
\text { potential. }\end{array}$ \\
\hline 9 & $\begin{array}{l}\text { Global attraction: Its interpretation exceeds } \\
\text { the previous category in that the attraction } \\
\text { induces global tourism flow and visits to the area } \\
\text { independent from geographical distance }\end{array}$ & $\begin{array}{l}\text { In Hungary there are few of them such as Budapest and the Hungaroring } \\
\text { Formula } 1 \text { race track. }\end{array}$ \\
\hline
\end{tabular}

Source: Aubert A. et al 2010

showed that functioning tourism generating attractions can be found in 207 settlements $(31.55 \%$ of the settlements in the region). Tourism demand was investigated by the presence of any commercial or private accommodations. Data showed that 112 settlements (17.07\%) had statistically detectable amount of accommodation turnover.

In the second phase the relationship between the spatial appearance of the tourism attractions and the presence of the guest flow of the accommodations was analysed and it uncovered numerous anomalies. Out of the 226 settlements with any level or form of tourism attraction and/or tourism accommodation demand, we identified only 81 combined a tourist attraction with statistically demonstrated accommodation demand. So the majority of the settlements possess no adequately functioning tourism where supply and demand are present in a balanced manner and thus we can conclude that the existing attractions in general cannot generate tourism demand to the settlements.
The next steps included the data collection and visualisation of the spatial allocation of tourism support sources. Results proved that the majority of the region's settlements $(405,61.73 \%)$ had neither tourism supply nor support. Interestingly, there were 141 settlements with generated tourism supply but without any financial support for tourism. However, the more intriguing phenomenon was that there were 49 settlements with detected financial tourism support but without any tourism attractions. The number of settlements where tourism attractions and tourism supports were present at the same time was low, only $9.3 \%$ of the analysed settlements (61 altogether).

The last stage of analysis investigated the relationship between the spatial functioning of tourism and the settlement development level. The survey showed that settlements with tourism supply and demand are not necessarily the most developed ones, meaning that tourism cannot be the only way for economic prosperity. However, it was proved that the majority of the most developed 
settlements are characterised by well-functioning tourism supply and demand.

Summing up the findings, important lessons can be learnt from such demonstrated anomalies where tourism demand and supply can be found not necessarily together with the presence of tourism attractions or products or, where tourism support is also allocated at such settlements where there is no (real) tourism attraction or product.

The presented research can therefore provide an impetus for the research and practice of the complex relationships between regional development and tourism, rural development and tourism as well as for the monitoring of the application of EU financial support in favour of their most beneficial social-economic utilisation.

One of the important results of this research is that its methodology can be easily used in any other European Union member countries, both on regional and national levels. Since all the member states need to serve statistical data to Eurostat, these data are reliable and comparable. It is not only Hungary that produces anomalies in the practice and theory of tourism development, so it would be a relevant topic and area of research to make a comprehensive survey in the European Union as well. Another aspect and direction of this work is to use this method and approach in any other member countries of the European Union as part of the monitoring process of the financial resources since the more adequate and detailed the monitoring process is, the more we learn to create a better and more effective regional policy.

Turning back to the question of whether we can see a balanced or an unbalanced development of tourism in South Transdanubia, we can state that further efforts should be made by the decision makers in order to avoid the revealed anomalies and so we would be able to achieve a more professional and more focused regional development of tourism industry in South Transdanubia.

Further directions of this research may be the application of more in-depth quality studies to be able to demonstrate more particular and more detailed results and relevancies. One of these directions may be the investigation of both tourism demand and supply where not only the existence but the rate and measures of the indicators can be examined.

\section{REFERENCES}

105/2015. (IV. 23.) Governmental Regulation (Hungarian Government).

ARCHER, B., FLETCHER, J. (1996): The economic impact of tourism in the Seychelles. Annals of Tourism Research 23(1), 32-47. https://doi.org/10.1016/0160-7383(95)00041-0

ARMSTRONG, H. W., GIORDANO, B., THANASIS, K., MACLEOD, C., OLSEN, L. S., SPILANIS, I. (2012): The European Regional Development Fund and Island Regions: An Evaluation of the 2000-06 and 2007-13 Programs. Island Studies Journal $7(2), 177-198$.
AUBERT, A., JÓNÁS-BERKI, M., MARTON, G., PÁLFI, A. (2015): Region specific characters of tourism in East-Central Europe. Acta Geographica Universitatis Comenianae 59(1), 21-33.

AUBERT, A., CSAPÓ, J., PIRKHOFFER, E., PUCZKÓ, L., SZABÓ, G. (2010): Complex Spatial Delimitation Methods of Tourism Destinations in South Transdanubia. Hungarian Geographical Bulletin 2010(3), 271-287.

BACHTLER, J., WREN, C. (2006): Evaluation of European Union Cohesion policy: Research questions and policy challenges. Regional Studies 40(2), 143-153. https://doi .org/10.1080/00343400600600454

BECKER, S. O., EGGER, P. H., VON EHRLICH, M. (2010): Going NUTS: The effect of EU Structural Funds on regional performance. Journal of Public Economics 94(9-10), 578-590. https:// doi.org/10.1016/j.jpubeco.2010.06.006

BOSCH-DOMĖNECH, A., ESCRIBANO, C. (1998): Regional allocation of public funds: an evaluation index. Environment and Planning A 20(10), 1323-1333. https://doi.org/10.1068/a201323

BUSILlO, F., MUCCIGROSSO, T., PELLEGRINI, G., TAROLA, O., TERRIBILE, F. (2010): Measuring the Impact of the European Regional Policy on Economic Growth: a Regression Discontinuity Design Approach. Working Papers 6/10, Sapienza University of Rome, DISS.

BUTLER, R. (1980): The concept of a tourist area cycle of evolution: implications for a management of resources. Canadian Geographer 24(1), 5-12. https://doi.org/10.1111/j.1541-0064.1980 .tb00970.x

COLE, S. (2007): The Regional Science of Tourism: An Overview. The Journal of Regional Sciences and Policy 37(3), 183-192.

CONNELL, J., PAGE, S. J., BENTLEY, T. (2009): Towards Sustainable Tourism Planning in New Zealand: Monitoring Local Government Planning under the Resource Management Act. Tourism Management 30(6), 867-877. https://doi.org/10.1016/j .tourman.2008.12.001

CONRADY, R., BUCK, M. (Eds) (2010): Trends and Issues in Global Tourism 2010. Springer-Verlag Berlin Heidelberg. https://doi.org/10.1007/978-3-642-10829-7

CROMPTON, J. L. (2006): Economic Impact Studies: Instruments for Political Shenanigans? Journal of Travel Research 45(1), 67-82. https://doi.org/10.1177/0047287506288870

CROMPTON, J. L., LEE, S., SHUSTER, T. J. (2001): A Guide for Undertaking Economic Impact Studies: The Springfest Example. Journal of Travel Research 40(1), 79-87. https://doi .org/10.1177/004728750104000110

DESKINS, J., SEEVERS, M. T. (2011): Are State Expenditures to Promote Tourism Effective? Journal of Travel Research 50(2), 154-170. https://doi.org/10.1177/0047287510362785

HALL, C. M. (2008): Tourism Planning: Policies, Processes and Relationships. Pearson Education Limited, Harlow, England.

DWYER, L., FORSYTH, P., SPURR, R. (2004): Evaluating tourism's economic effects: new and old approaches. Tourism Management 25(3), 307-317. https://doi.org/10.1016 /S0261-5177(03)00131-6

DWYER, L., KIM, C. (2010): Destination Competitiveness: Determinants and Indicators. Current Issues in Tourism 6(5), 369-414. https://doi.org/10.1080/13683500308667962

ESPON Monitoring Committee (2006): Preparatory Study of Spatially Relevant Aspects of Tourism. ESPON project 1.4.5 Final Report, 22 January 2006.

EUROPEAN COMMISSION (2015): Culture and Tourism Final Report - Work Package 9. Ex post evaluation of Cohesion Policy programmes 2007-2013, focusing on the European Regional Development Fund (ERDF) and the Cohesion Fund (CF). European Commission, Brussels. 
FONT, X., AHJEM, T. E. (1999): Searching for a balance in tourism development strategies. International Journal of Contemporary Hospitality Management 11(2-3), 73-77. https://doi .org/10.1108/09596119910250698

HALL, C. M., BOYD, S. W. (2005): Nature-based tourism in peripheral areas: development or disaster? Buffalo, N.Y.: Channel View Publications.

HALL, C. M. (2012): Spatial analysis: A critical tool for tourism geographies. In: Wilson, J. (ed.): The Routledge Handbook of Tourism Geographies, Routledge, London, pp. 163-173.

HCSO (Hungarian Statistical Office) database on the settlement level index, 2013. www. ksh.hu

IMRAN, M. M., BHAT, M. S. (2013): Identification of Tourist Potential Regions for Balanced Tourism Development in Pahalgam Tourist Destination of Kashmir Valley. Geography 2(4), 189-190.

JOPP, R., DELACY, T., MAIR, J. (2010): Developing a framework for regional destination adaptation to climate change. Current Issues in Tourism 13(6), 591-605. https://doi .org/10.1080/13683501003653379

LEW, C. M., HALL, C. M., TIMOTHY, D. (2008): World Geography of Travel and Tourism: A Regional Approach. Oxford: Elsevier.

MEYER, M. (2011): Tourism versus spatial order: mutual relations. Tourism 21(1-2), 25-32. https://doi.org/10.2478 /v10106-011-0003-7

MOHL, P., HAGEN, T. (2010): Do EU structural funds promote regional growth? New evidence from various panel data approaches. Regional Science and Urban Economics 40(5), 353-365. https://doi.org/10.1016/j.regsciurbeco.2010.03.005

RODRÍGUEZ-POSE, A., FRATESI, U. (2003): Between Development and Social Policies: The Impact of European Structural
Funds in Objective 1 Regions. European Economy Group Working Papers 28, European Economy Group.

SÁNCHEZ-RIVERO, M., CÁRDENAS-GARCÍA, P. J. (2014): Population Characteristics and the Impact of Tourism on Economic Development. Tourism Geographies 16(4), 615-635. https://doi .org/10.1080/14616688.2014.889207

SHARPLEY, R. (2015): Tourism: A vehicle for development? In: Sharpley, R., Telfer, D. J. (eds.) Tourism and Development: Concepts and Issues. Channel View Publications.

VIKEN, A., GRANAS, B. (2014): Tourism destination development: turns and tactics. Farnham, Surrey. England; Burlington, VT: Ashgate Publishing Company. eBook.

TERLUIN, I. (2003): Differences in economic development in rural regions of advanced countries: an overview and critical analysis of theories. Journal of Rural Studies 19, 327-344. https://doi .org/10.1016/S0743-0167(02)00071-2

THEOBALD, W. F. (Ed.) (2011): Global tourism. 3rd edition. Taylor and Francis.

VON BERGNER, N. M., LOHMANN, M. (2014): Future Challenges for Global Tourism - A Delphi Survey. Journal of Travel Research 53(4), 420-432. https://doi.org/10.1177/0047287513506292

VARJÚ, V., SUVÁK, A., DOMBI, P. (2014): Geographic information systems in the service of alternative tourism - methods with landscape evaluation and target group preference weighting. International Journal of Tourism Research 16(5), 496-512. https://doi.org/10.1002/jtr.1943.

WILLIAMS, D. C., JR., CARTEE, C. P. (1991): Measuring Travel and Tourism Impacts on a State's Economy: Policy Implications. Journal of Economics and Finance 15(2), 161-70.

YAOQING, Y. (2011): Potential evaluation of tourism development based on multi-level grey theory. 2011 International Conference on Management Science and Industrial Engineering (MSIE), pp. 546-549. 